\title{
Follicular Mucinosis and Follicular Mycosis Fungoides: Clinicopathological Evaluation of Seven Cases
}

\author{
Folliküler Müsinozis ve Folliküler Mikozis Fungoides: \\ Yedi Olgunun Klinikopatolojik Değerlendirilmesi
}

\author{
Banu YAMAN ${ }^{1}$, Bengü GERÇEKER TÜRK², Günseli ÖZTÜRK², İlgen ERTAM², \\ Gülşen KANDILOĞLU', Taner AKALIN'
}

Department of 'Pathology and '2Dermatology, Ege University, Faculty of Medicine, IZMIR, TURKEY

\begin{abstract}
Objective: Follicular mucinosis is a disease characterized by follicular degeneration and mucin accumulation. It can be seen in mycosis fungoides, although idiopathic or forms associated with other diseases are also known. Follicular mycosis fungoides is a type of mycosis fungoides with different clinicopathological and prognostic features.
\end{abstract}

Material and Method: Seven cases with follicular centered lesions and multiple biopsies (2-6) were included. Cases were evaluated according to their clinical, histological and immunophenotypical features and follow-up data.

Results: All cases were male, and the mean age was 40.3 (range 18-61). Clinical complaints were follicular prominence, erythema and alopecia at head and neck, trunk, and lower limbs.

Follicular mucinosis (6/7), and dermal lymphoid infiltration showing minimal-intensive folliculotropism accompanied by eosinophils was seen. Lymphoid infiltration was composed of small-medium sized cells, with scattered hyperchromatic nuclei in six cases. In one case there was only minimal cytological atypia. Intense folliculotropism of atypical lymphocytes and dense dermal infiltration without follicular mucinosis was seen in one case.

Local and/or systemic treatments were applied and partial remission was achieved histologically. In three cases new and increasing lesions were seen. Density of infiltration and atypia were increased.

Conclusion: The findings supported the opinion that follicular mucinosis is an important finding seen in mycosis fungoides. There can be important differences concerning the amount of infiltration and degree of atypia. In cases where the density of infiltration associated with follicular mucinosis is not diagnostic for MF, there can be progression over time. Long-term follow up is necessary in such cases where the differential diagnosis is difficult.

Key Words: Mucinosis, Follicular, Mycosis fungoides, Therapeutics, PUVA therapy

(Turk Patoloji Derg 2013, 29:108-116)

Received : 16.12.2012 Accepted : 19.03.2013
ÖZ

Amaç: Folliküler müsinozis, müsinöz folliküler dejenerasyonla karakterli bir hastalıktır. Mikozis fungoideste görülebildiği gibi idiopatik veya bazı hastalıklara eşlik eden formları da bilinmektedir. Folliküler mikozis fungoides, folliküler müsinozisin eşlik edebildiği klinik, histolojik ve prognostik özellikleri farklı bir mikozis fungoides formudur.

Gereç ve Yöntem: Birden fazla biyopsisi (2-6) bulunan ve lezyonları follikül merkezli olan yedi olgu çalışmaya dahil edildi. Olgular klinik, histolojik, immünhistokimyasal özellikleri ve tedaviye yanıtları açısından değerlendirildi.

Bulgular: Olguların tümü erkek olup, yaşları 18-61 arasında (ortalama 40,3) idi. Kliniğe başvuru yakınmaları baş-boyun, gövde ya da alt ekstremitelerde folliküler belirginleşme, kızarıklık ve kıl kaybı idi.

Biyopsilerde folliküler müsinozis (6/7), ve dermada minimal-yoğun follikülotropizm gösteren değişken oranda eozinofillerin de eşlik ettiği lenfoid infiltrasyon görüldü. Lenfoid infiltrasyon altı olguda bir kısmı hiperkromatik nukleusa sahip küçük-orta boy hücrelerden oluşmakta idi. Bir olguda minimal sitolojik atipi izlendi. Müsin izlenmeyen bir olguda atipik lenfositlerin belirgin follikülotropik infiltrasyonu yanısıra yoğun dermal infiltrasyon görüldü.

Lokal ve/veya sistemik tedaviler uygulanan olgularda tedaviyle histolojik olarak da kısmi yanıt izlendi. Takiplerde üç olguda lezyonlarda artış, yeni lezyon çıkışları ve histolojik olarak da atipi ve infiltrasyonun arttığı görüldü.

Sonuç: $\mathrm{Bu}$ çalışma, folliküler müsinozisin, folliküler mikozis fungoidese eşlik eden önemli bir bulgu olduğunu, buna eşlik eden infiltrasyon miktarı ve atipi derecesi açısından büyük farklar olabildiğini göstermektedir. Başlangıçta folliküler müsinozise eşlik eden infiltrasyonun mikozis fungoides tanısı için yeterli olmadığı olgular süreç içinde mikozis fungoidese dönüşebilmektedir. Klinik ve histolojik bulguları değerlendirerek ayırımın güç olduğu bu tür olgularda uzun süreli takip gereklidir.

Anahtar Sözcükler: Müsinosis, Folliküler, Mycosis fungoides, Terapötik, PUVA tedavisi

Correspondence: Banu YAMAN

Ege Üniversitesi Tip Fakültesi, Patoloji Anabilim Dalı, IZZMIR, TURKEY

E-mail: drbanuyaman@yahoo.com Phone: +90 2323903709 


\section{INTRODUCTION}

Pinkus first defined "Alopecia mucinosa" as a mucinous follicular degeneration that leads to alopecia in 1957 (1). This term became follicular mucinosis when it was shown that follicular mucinous degeneration was not always associated with alopecia (2). Mucin accumulation in the follicle epithelium is defined in many inflammatory and neoplastic diseases but the pathogenesis is not clear. Follicular mucinosis (FM) is a disorder characterized by mucinous follicular degeneration with a clinical presentation of follicular prominance, alopecia and/or comedone-like well-limited plaques $(3,4)$. It is classified into two main forms as the benign idiopathic form and the mycosis fungoides (MF)-related secondary form in the literature $(2,4,5)$. In addition, cases associated with various diseases have also been reported $(3,6)$. Articles reporting idiopathic follicular mucinosis progressing to lymphoma are also present $(7,8)$. FM's relationship with the development of lymphoproliferative disease has been clearly shown (9-12). Secondary FM is usually associated with MF and its variants, but its relationship with other lymphoproliferative disorders such as cutaneous B-cell lymphoma, chronic lymphocytic leukemia and Hodgkin's lymphoma has also been demonstrated (13-15).

Clinical follicular involvement in mycosis fungoides has been known since the 1960s. The term follicular MF has been used by Kim (16) in 1985, and case series have been reported in the following years $(13,17)$. Despite indefinite or absent interfollicular epidermis involvement in follicular MF cases, mucinosis in the follicle epithelium and neoplastic lymphoid infiltration have been highlighted. Rongliotti et al. (18) reported that eccrine and follicular infiltration could be prominent in MF patients with indefinite epidermotropism and helpful in the diagnosis of MF.

This group of MF cases whose clinical and histological characteristics as well as response to treatment are different is defined as a separate entity under the name folliculotropic/follicular variant in the WHO-EORTC classification. Gerami and Guitart $(19,20)$ defined the various clinical and histological characteristics and subtypes of follicle involvement. As mentioned in sources, folliculotropism and syringotropism can also be found in the in the conventional MF group with their clinical and histological characteristics.We report on cases showing follicle-centered involvement and mostly accompanied by follicular mucinosis under the MF heading in this study.

\section{MATERIAL and METHOD}

97 cases followed as MF or follicular mucinosis between 2000 and 2012 have been reviewed. Cases with clinical follow-up and more than one biopsy, lymphocytic exocytosis in the follicular epithelium accompanied by follicular mucinosis, or clear folliculotropic lymphoid infiltration were included in the study. Seven FM and/or follicular MF cases with clinical follow-up and multiple (2-7) biopsies were evaluated for their clinical, histological and immunophenotypic characteristics in this study.

Hematoxylin-eosin (HE), periodic acid Schiff - Alcian blue (PAS-AB) stained slides and immunohistochemical examination sections belonging to all the biopsies of the cases were re-evaluated. The mucin amount in the follicle, the intensity and pattern of lymphocytic infiltration, the degree of cellular atypia, and other possible accompanying findings such as the presence of eosinophils were recorded.

Clinical observation and treatment of all cases were reviewed from the medical records and patients were called for follow-up when necessary.

\section{RESULTS}

All seven patients included in the study were male and their ages were between 18 and 61 (mean 40.3) years. Three cases had a family history of psoriasis. The clinical complaints were follicular prominence in the body, scalp and/or face, rash, and hair loss in five patients. Two cases presented with leg and gluteal area lesions (one with nodule formation and the other with follicular prominence and alopecia) but the history revealed similar lesions in the facial area and arms too. Clinical findings, treatment options and prognosis data of the cases are summarized in Table I.

Follicular mucinosis at various rates was observed in the biopsies of six patients, and no mucin was observed in one patient. The mucin observed in the follicular epithelium led to expansion of the follicles and was most noticeable in hematoxylin-eosin preparations. Mucin accumulation was quite apparent and easily identifiable in all biopsies in three cases. Mucin accumulation was found to be positive with alcian blue on histochemical examination. Comedonelike cystic expansion was seen in the follicles in one case. Follicular epithelial hyperplasia was observed in three cases.

Folliculotropism consisting of small-to-medium-sized lymphocytes infiltrating the follicular epithelium was seen in all cases. In addition to folliculotropism, there was dermal infiltration that was found to be perifollicular and perivascular in four cases, spreading to the interstitial space 


\begin{tabular}{|c|c|c|c|c|c|c|c|}
\hline 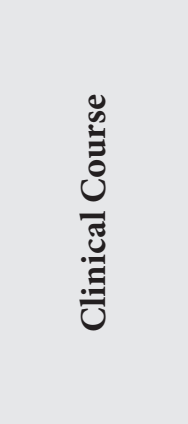 & 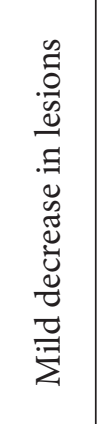 & 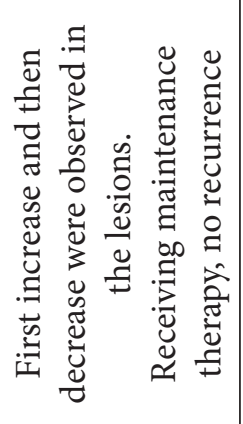 & 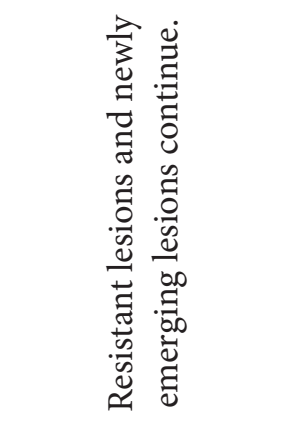 & 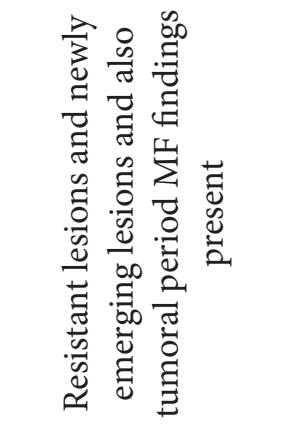 & 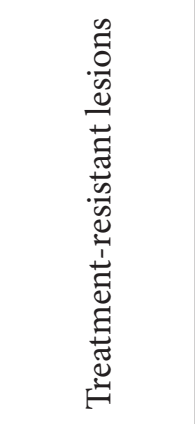 & 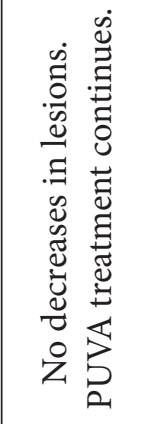 & 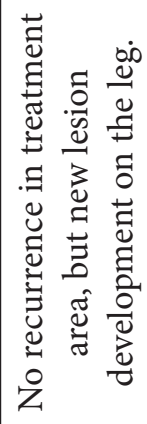 \\
\hline 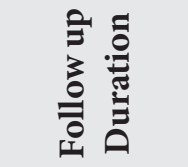 & 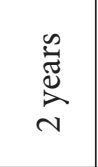 & 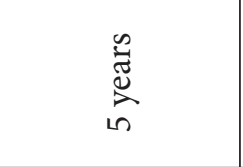 & $\underset{\tilde{J}}{\stackrel{\infty}{\tilde{U}}}$ & 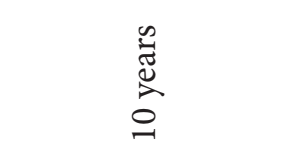 & 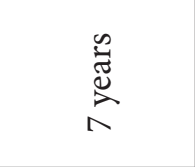 & 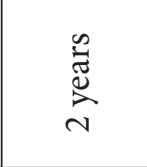 & 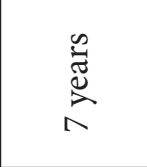 \\
\hline 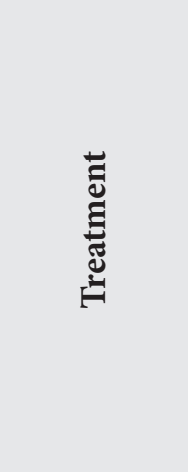 & $\begin{array}{l}\mathbb{4} \\
5 \\
2 \\
4 \\
4 \\
0 \\
0 \\
0 \\
0 \\
0 \\
0 \\
0 \\
m\end{array}$ & 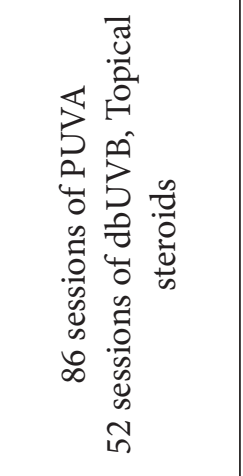 & 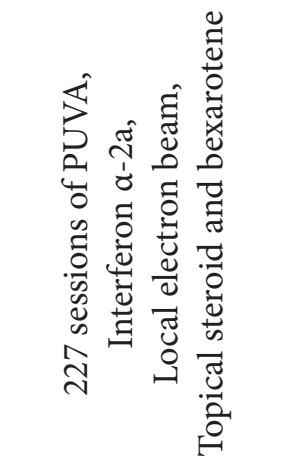 & 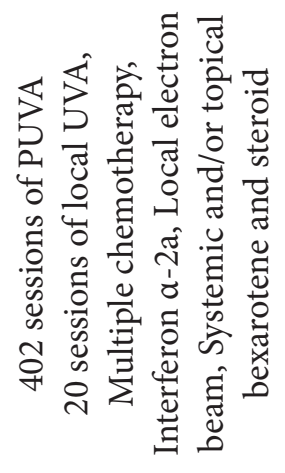 & 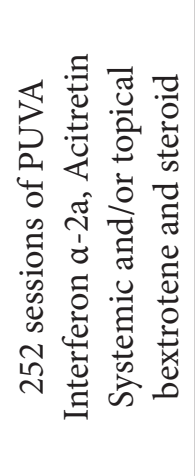 & 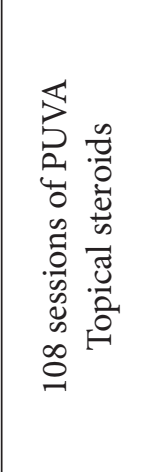 & 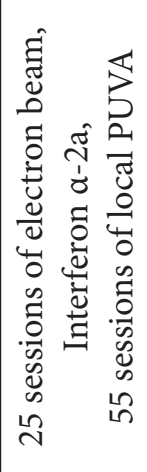 \\
\hline 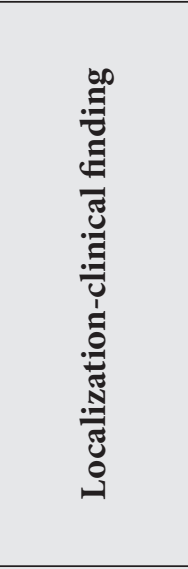 & 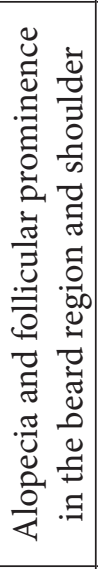 & 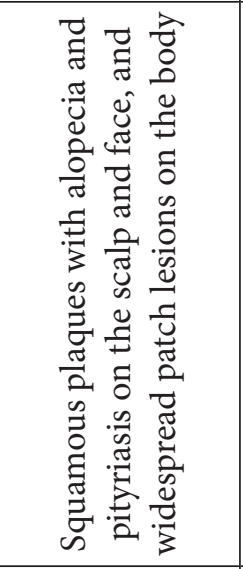 & 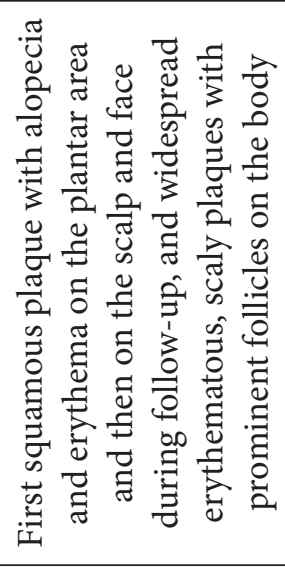 & 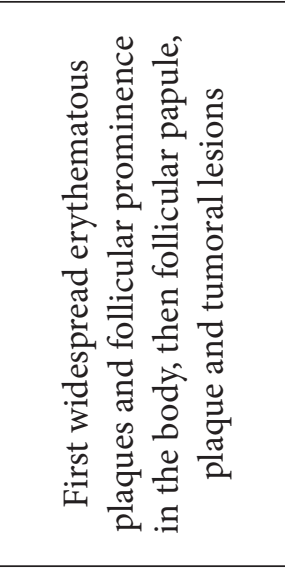 & 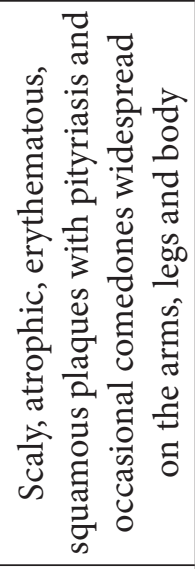 & 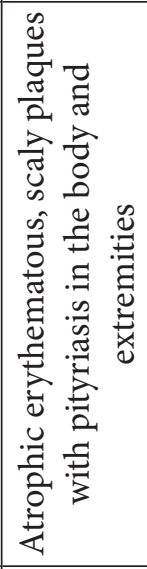 & 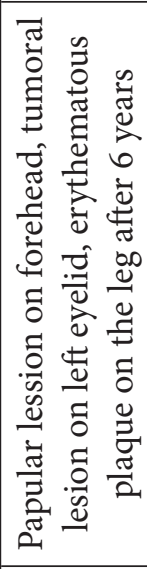 \\
\hline 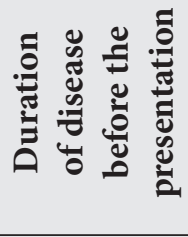 & 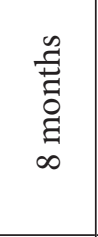 & 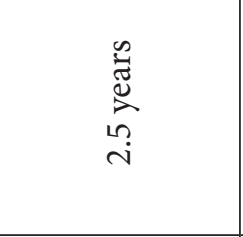 & $\begin{array}{l}\vec{\Xi} \\
\stackrel{\Xi}{二}\end{array}$ & 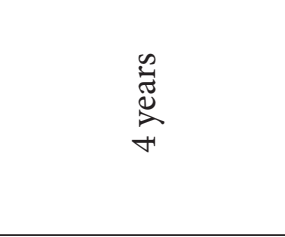 & 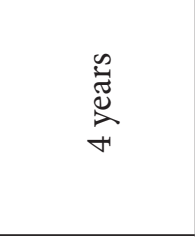 & 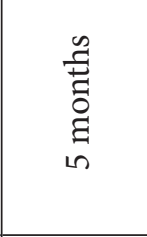 & 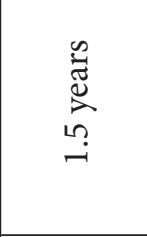 \\
\hline 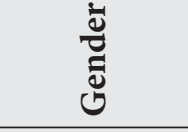 & $\Sigma$ & $\Sigma$ & $\Sigma$ & $\Sigma$ & $\Sigma$ & $\Sigma$ & $\Sigma$ \\
\hline 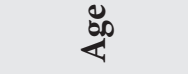 & $\stackrel{\infty}{-}$ & $\hat{n}$ & 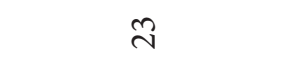 & $\not{F}$ & กิ & for & $\overrightarrow{6}$ \\
\hline נ̋ & $\neg$ & 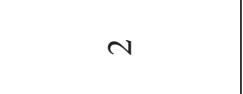 & $m$ & 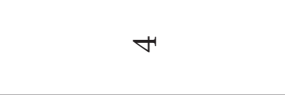 & in & 6 & $\wedge$ \\
\hline
\end{tabular}


in two cases and diffuse in two cases. This infiltration was accompanied by eosinophils and histiocytes at various rates.

Lesions were limited to the face and shoulder area in our no. 1 patient (18 years old) who was yet at two-year followup. In addition to mild follicular mucin accumulation, focal folliculotropism of small hyperchromatic lymphocytes, and occasional perifollicular and perivascular lymphoid infiltration were seen in the biopsies (Figure 1A-D). The defined findings were not found sufficient for the diagnosis of MF. This patient's lesions decreased with PUVA treatment and are being clinically monitored.

One of the three cases with intense mucin accumulation (no. 2) had been followed up for five years and there was no significant difference in the biopsies regarding the mild infiltration intensity and cytological atypia. However, the lesions were clinically observed to increase in the process.
The patient responded to treatment and is followed up with maintenance therapy without any lesions at the moment.

The first biopsies of two cases (cases no. 3 and 4 with sixand ten-year follow-up) showed folliculotropism of smallto-medium-sized hyperchromatic lymphocytes as well as perifollicular and perivascular infiltration. Follicular epithelial infiltration intensity and the degree of cytological atypia had increased and dermal infiltration had been added in later biopsies. Although case no. 3 was initially clinically thought to be idiopathic follicular mucinosis due to the absence of widespread lesions, the lesions were seen to be resistant to treatment in follow-up and later biopsies revealed increasing lymphoid infiltration intensity and atypia (Figure 2A-G).

Case no. 4 had dense mucin accumulation and was diagnosed as follicular MF from the first biopsy with the
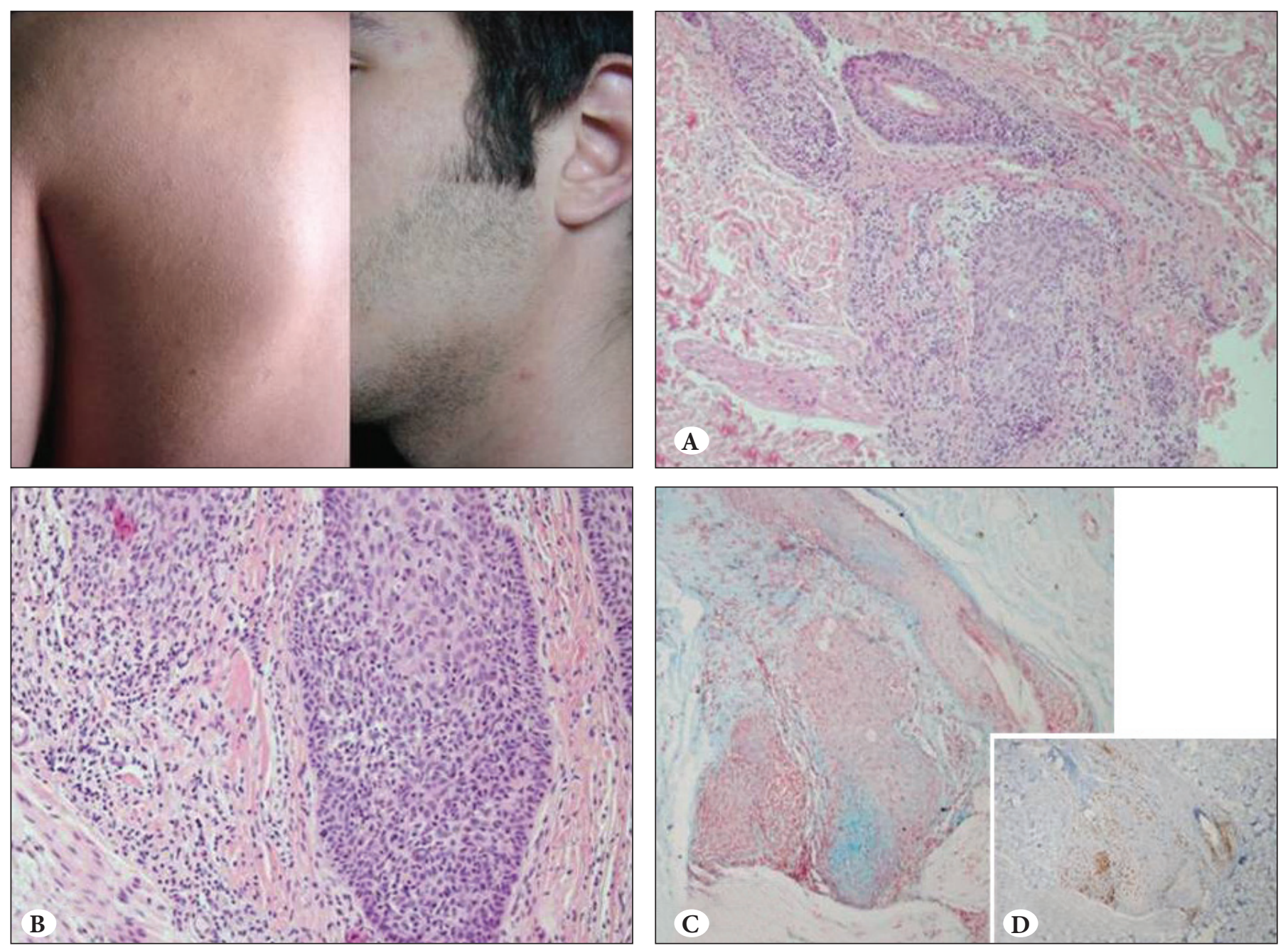

Figure 1: Follicular prominence and alopecia areas in the face and scapular region in the first case (18 years old).

(A) Perifollicular lymphoid infiltration (HE x40), (B) Marked folliculotropism (HE x200), (C) Mucin accumulation with PAS-AB, (D) CD3 positivity in lymphocytes (x100). 

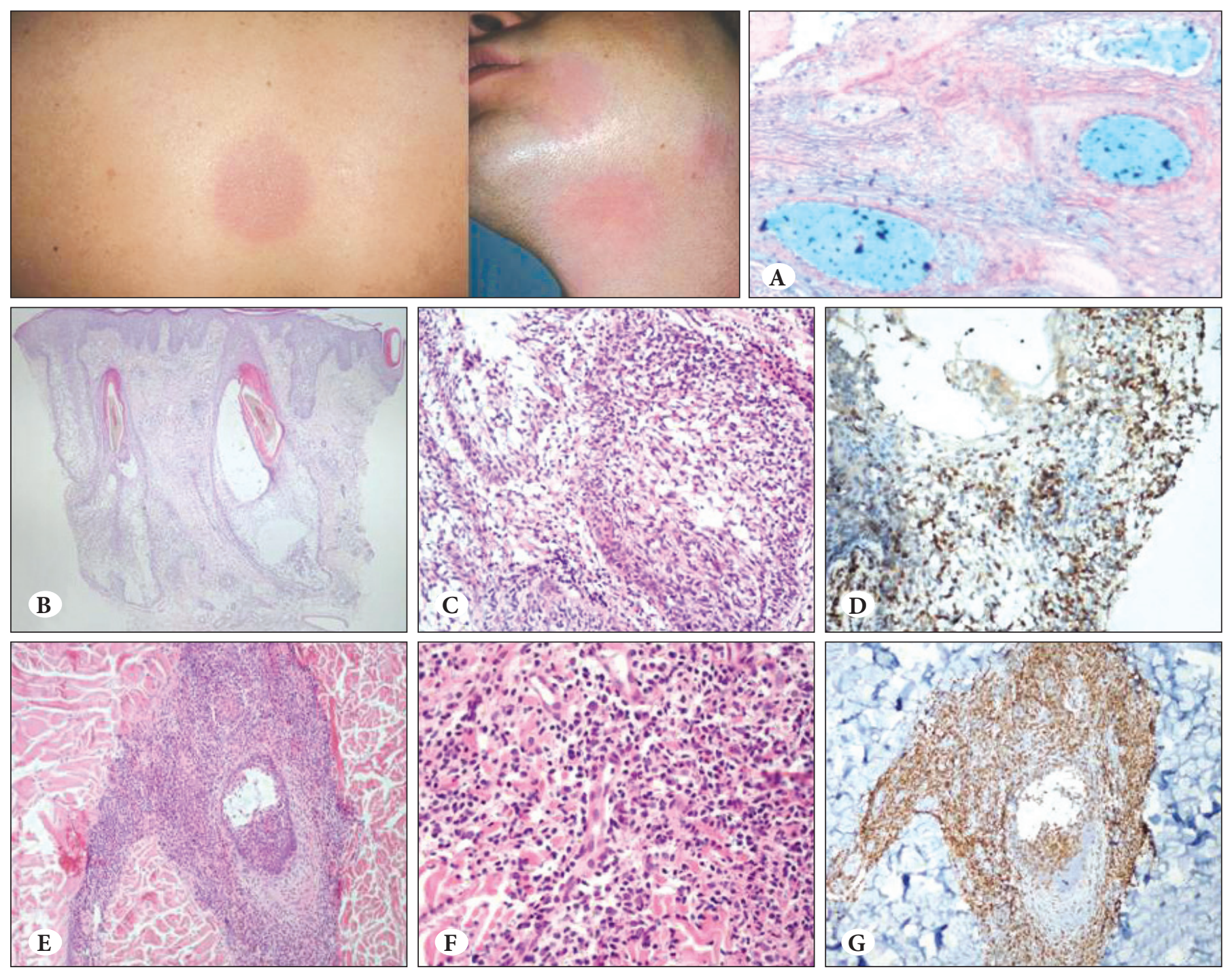

Figure 2: Erythematous alopecic plaque lesions in the face and back region in the third case (23 years old).

Lymphoid infiltration showing significant mucin accumulation and folliculotropism in the pre-treatment biopsy. (A) PAS-AB x100, (B) HE x40, (C) HE x200, (D) CD3 positivity x200), Smaller amount of mucin and increased lymphoid infiltration in the follow-up biopsy. (E) HE x40, (F) HE x40, (G) CD3 x200).

clinical and histological findings. Despite treatment, tumoral MF with increasing cytological atypia and diffuse dermal infiltration was seen in biopsies with follow up of more than 10 years (Figure 3 ).

Case no. 5 with little mucin accumulation had small-to-medium-sized hyperchromatic lymphocyte folliculotropism and perivascular perifollicular infiltration, as well as comedone-like expansions in follicles, and an inflammatory reaction including foreign body type giant cells related to the follicle rupture in one biopsy.

Case no. 6 had folliculotropism of lymphocytes with medium-sized hyperchromatic nuclei and a monomorphic appearance together with perivascular - perifollicular and focal dermal infiltration, as well as epithelial proliferation and mucin accumulation.

No mucin accumulation was seen in case no. 7. The infiltration observed in the initial biopsies of this case consisted of marked folliculotropism as well as diffuse dermal infiltration of small-to-medium-sized hyperchromatic lymphocytes. Post-treatment biopsies showed a significant decrease in infiltration intensity and the number of atypical cells. Results were evaluated as a good response to the treatment. The new lesion that developed in the leg after six years was diagnosed histologically as MF.

Immunohistochemical examination revealed follicular and dermal infiltration mostly composed of CD3- and 

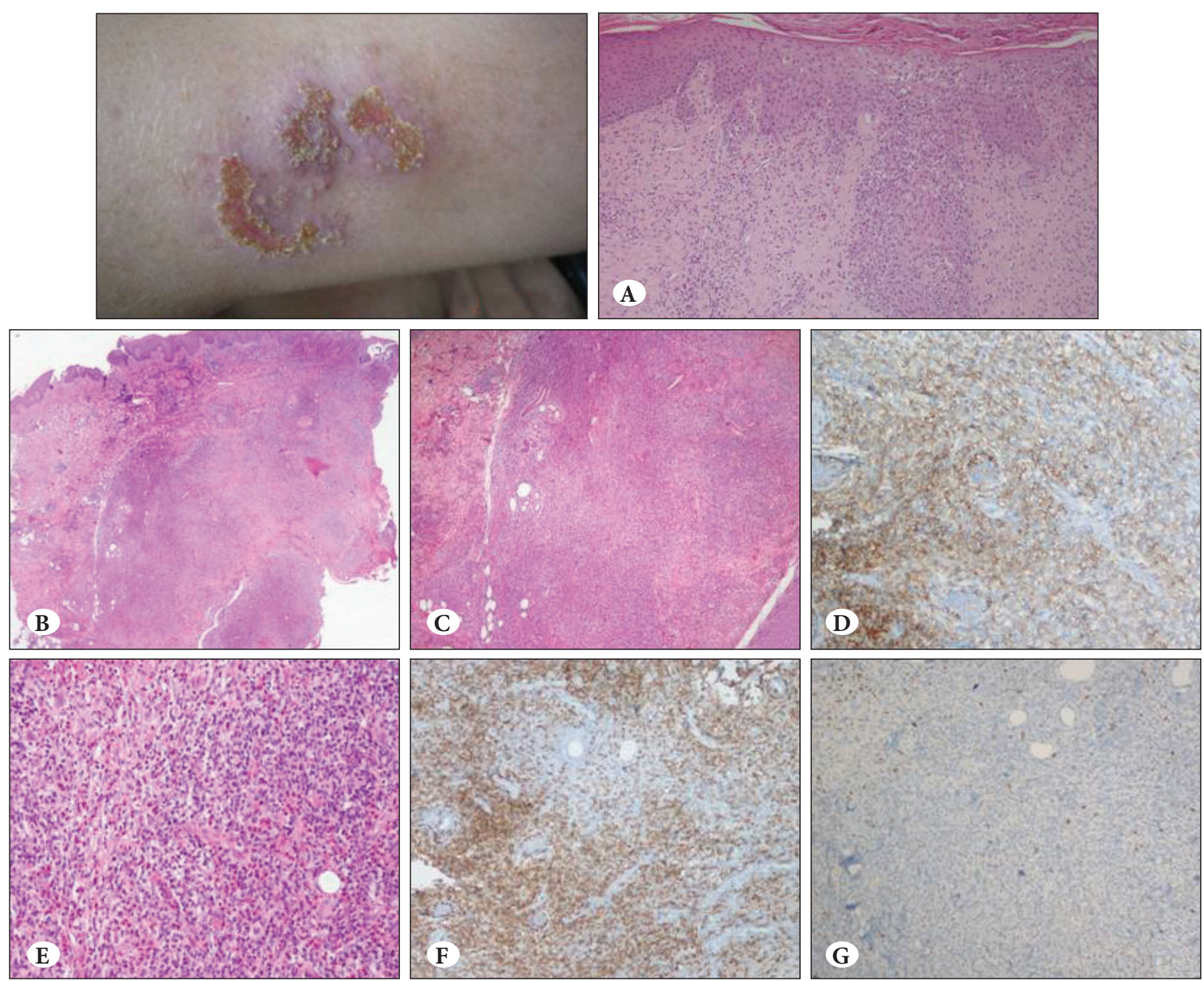

Figure 3: Erythematous, partially infected lesion in the extremity seen at the beginning in case no. 4 with tumoral MF development ten years after the diagnosis.

(A) Follicle-centered lymphoid infiltration in the first biopsy (HE x100), Intense dermal lymphoid infiltration accompanied by eosinophils in the biopsy obtained from the tumoral lesion (B) HE x40, (C) HE x200, (D) CD3 x400, (E) HE x40), (F) CD4 x200, (G) CD8 x200).

CD4-positive T lymphocytes in all cases. CD8-positive T lymphocytes were significantly less than CD4-positive $\mathrm{T}$ cells.

Combination therapy was often used for the patients. Follow-up periods were between 2 and 10 years. Six cases were started treatment with Psoralene-ultraviolet A (PUVA). Interferon was used in four cases refractory to PUVA treatment, oral bexarotene in two cases, acitretin in one case, topical bexarotene in three cases and agents containing potent topical steroids in all cases. A partial response with treatment was histologically observed in these cases. However, atypia and infiltration were seen to increase histologically in the clinically increasing and newly emerging lesions in the follow-up. The use of local electron beam therapy primarily and then interferon was preferred in one case (no. 7) because of lesions being localized in the eye area and tumoral characterized. This patient achieved a complete remission for 5 years, but development of new lesions in the lower extremities were then observed and remission was achieved in this lesion with local PUVA therapy. Tumoral stage MF findings were found in one case (no. 4) 10 years later. This case that did not respond to administered treatment received multiple chemotherapy and then local electron beam therapy. Remission has still not been achieved in five of the cases and new lesion formation continues. No disease-related mortality was observed in this series. 


\section{DISCUSSION}

Follicular mucinosis is a rarely seen epidermal reaction pattern characterized by mucinaccumulation in hair follicles. It can accompany inflammatory processes (such as eczema, lupus dermatitis or insect bites) or lymphoproliferative diseases. $(3,6,21)$. Follicular mucinosis characterized by mucin accumulation and macrophage-eosinophil as well as lymphocytic infiltration with folliculotropism in the outer hair sheath (3) was first defined by Pinkus (1) in detail. Two clinical types were emphasized as idiopathic follicular mucinosis and lymphoma-related follicular mucinosis in different publications $(8,22)$. Some articles report a chronic benign form persisting for a long time between these two forms (22), and there are various articles that report the MF clinical picture emerging in later periods in cases with long-term follow-up $(7,8)$.

One study reported $89 \%$ of FM cases developing lymphoma were diagnosed with MF in a few years (8). Mycosis fungoides may be associated with FM or can occur several years after the FM diagnosis $(8,11,12,23)$.

Follicular MF is an epidermotropic lymphoproliferative disease primarily observed in the follicular epithelium and there may be significant mucinous accumulation although it is not necessarily accompanied by follicular mucinosis $(17,24)$. It becomes clinically apparent as follicular prominence, and superficial treatment methods are inadequate as lymphoid infiltration is observed in deeper tissue on histopathological examination $(25,26)$. It can be differentiated from classical MF with the clinical and histological features, resistance to the standard treatment and its persistence $(17,24)$.

We observed clinical follicular prominence and histologically follicle-centered deep lymphoid infiltration in the presented cases.

The differential diagnosis of idiopathic FM and lymphomarelated FM forms have been investigated for many years and the important parameters seem to be the patient's age, lesion location, and histological features $(8,10,22,27,28)$. However, many authors report that the two entities can be similar in terms of age, localization and histological features making the differential diagnosis very difficult $(4,8,10$, 27, 29). Although follicular MF is used as a synonym for lymphoma-related FM, but there are also cases of follicular MF where mucinosis is never observed.

The idiopathic form is often observed in the younger patients and in a head and neck location $(1,4)$. The second lymphoma-related form is observed at advanced ages (27).
Although this form is generally reported to be related to mycosis fungoides or Sezary syndrome (1), pediatric MF cases with concurrent or no FM (28-30), and middle-aged patients with idiopathic FM (3) have been reported.

Both lesions may have a head or neck location, but lesions are often observed in other parts of the body at the same time in the lymphoma-related form $(3,4)$. The clinical presantation of MF became more clear over time have been reported in cases where the first clinical finding was FM in the head and neck region $(9,10)$.

The lesions showed a wide spectrum in terms of location and age distribution in our study. The lesions located in the head and necks in four patients were observed in conjunction with body and extremity lesions except one case. New lesion development was observed in the lower extremities during follow up in a case (no 7) where the lesions were only localized to the face.

Cerroni et al. (4) stated that whether the lesion was solitary or multiple was an important parameter for the differential diagnosis. The lesions were reported to be single and solitary in most idiopathic FM cases while they were rarely started out as solitary in the lymphoma-related group. Various studies emphasize that the idiopathic form is more frequently in the form of solitary lesions and may regress in a few years $(3,13,31-33)$ but the presence of idiopathic FM case (34) with generalized lesions shows that there may be overlap in this regard.

We had two cases (no. 2 and 3) with initial limited, solitary lesions, and the development of more generalized lesions during treatment and follow-up. No progression was observed during two years of follow up period in our case no 1 with localized lesions on the face and shoulders.

The amount of mucin and infiltration characteristics observed in the hair follicles in FM and FM-related MF may show significant differences in terms of histological features $(4,6,8,35)$. Despite larger mucin pools in idiopathic FM, lymphocyte infiltration is reported to be more prominent in lymphoma-related FM (3), but mild or significant mucin pooling may be found in either group. Likewise, an intense lymphocytic infiltration can be observed in idiopathic FM (35). This is demonstrated by up to $35 \%$ of lymphomarelated cases being evaluated as idiopathic FM with the first biopsy $(4,23)$.

Lymphocytes with an irregular contour and large, hyperchromatic nuclei were more often defined in the lymphoma-related form in a study morphologically evaluating a large number of cases from both groups $(3,17)$. 
The presence of eosinophils at various rates and intensities have been reported in both groups $(3,17,36)$.

The mucin accumulation varied from case to case and in different biopsies of the same case in our series. No mucin was observed in a follicular MF case determined in the tumoral stage. When evaluated together with the differences observed in terms of lymphoid infiltration, no correlation was seen between the mucin accumulation intensity and degree of atypia of the lymphoid infiltration.

While cytological atypia was mild or absent in the first biopsies of two cases (no. 2 and 3) in our series, lymphoid infiltration intensity as well as degree of cytological atypia was observed to increase in later biopsies. No cytological atypia was observed in the biopsies performed over the two-year of follow-up of case no. 1. Varying degrees of cytological atypia were present in the other cases.

There are also conflicting reports regarding immunohistochemical characteristics and TCR gene rearrangement in the literature. Rangioletti et al. (3) reported that CD4 + cells were three times more common in lymphoma-related FM while CD8+ cells were relatively more common in idiopathic FM in contrast. We have also seen lymphocytes to be immunohistochemically CD3 + while the CD8 + T cell number was significantly less compared to CD4 + cells in our cases.

T-cell monoclonality is used as a supporting finding in the diagnosis of follicular MF cases $(3,23,37)$. However, the presence of monoclonality in idiopathic FM cases as well shows that this cannot be used as an indicator of the clinical course $(3,4,13,35,38)$. Histological findings therefore still remain the most important parameter for the differential diagnosis.

Treatment of FM cases is different from the conventional MF cases, but there is no generally accepted standard of care (35). Response to narrow-band UVB or PUVA treatments that target the skin is often poor as the infiltration extends deeper along the follicle in these cases. Local or total electron beam treatment is reported to provide remission. Bexarotene may be used either alone or in combination with PUVA treatment $(25,26)$. These cases are reported to show a slow progress despite the persistent and active lesions (26). All cases presented here except one were resistant against skin-targeted therapies, and responded partially to the current treatment options either alone or in combination. However, as reported in the literature, they showed slow progress despite the persistent lesions and none of the cases had systemic involvement.
As the prognosis of idiopathic FM is not clear, $50 \%$ of idiopathic FM cases have histopathological features similar to cutaneous lymphoma, and some cases develop an MF clinical picture in the long-term, Cerroni et al. (4, 17) stated there were no definite morphological criteria to differentiate the idiopathic form and lymphoma-related form and idiopathic FM was a variant of MF with a longterm and non-aggressive clinical course.

We had one follicular mucinosis case with less infiltration and uncertain cytological atypia in our series, and there were also cases with uncertain atypia and infiltration at the beginning that progressed histologically and clinically during the follow-up. In addition, although remission was achieved with treatment in these patients in general, progressive cases were also observed. All these findings support the view idiopathic and/or lymphomarelated (follicular MF) cases with FM form a clinical and histological spectrum. This result points at the importance of FM cases without known etiology to be monitored as part of a spectrum.

In conclusion, we think that 1) Differentiating between FM and follicular MF with morphological and immunohistochemical findings is difficult, 2) Recurrences may develop in FM cases in time or they can convert into a follicular MF clinical picture, 3) patients should be followed for a long time, 4) follow-up with biopsy in cases that do not regress is appropriate. Our findings related to the treatment and clinical follow-up of these cases support the current notion that follicular MF cases require different treatment methods than conventional MF and are relatively refractory.

\section{REFERENCES}

1. Pinkus H: Alopecia mucinosa; inflammatory plaques with alopecia characterized by root-sheath mucinosis. AMA Arch Derm 1957, 76:419-424

2. Jablonska S, Chorzelski T, Lancucki J: Mucinosis follicularis Hautarzt 1959, 10:27-33

3. Rongioletti F, De Lucchi S, Meyes D, Mora M, Rebora A, Zupo S, Cerruti G, Patterson JW: Follicular mucinosis: A clinicopathologic, histochemical, immunohistochemical and molecular study comparing the primary benign form and the mycosis fungoides-associated follicular mucinosis. J Cutan Pathol 2010, 37:15-19

4. Cerroni L, Fink-Puches R, Bäck B, Kerl H: Follicular mucinosis A critical reappraisal of clinicopathologic features and association with mycosis fungoides and Sézary syndrome. Arch Dermatol 2002, 138:182-189

5. Braun-Falco O: Mucophanerosis intrafollicularis et seboglandularis. Dermatologische Wochenschrift 1957, 136:1289-1303 
6. Hempstead RW, Ackerman AB: Follicular mucinosis. A reaction pattern in follicular epithelium. Am J Dermatopathol 1985, 7:245-257

7. Sentis HJ, Willemze $R$, Scheffer E: Alopecia mucinosa progressing into mycosis fungoides. A long-term follow-up study of two patients. Am J Dermatopathol 1988, 10:478-486

8. Gibson LE, Muller SA, Leiferman KM, Peters MS: Follicular mucinosis: Clinical and histopathologic study. J Am Acad Dermatol 1989, 20:441-446

9. Wilkinson JD, Black MM, Chu A: Follicular mucinosis associated with mycosis fungoides presenting with gross cystic changes on the face. Clin Exp Dermatol 1982, 7:333-339

10. Binnick AN, Wax FD, Clendenning WE: Alopecia mucinosa of the face associated with mycosis fungoides. Arch Dermatol 1978, 114:791-792

11. Kanno S, Niizuma K, Machida S, Takahashi M, Ohkido M, Nagura H, Murakosi M, Mori T: Follicular mucinosis developing into cutaneous lymphoma. Report of two cases and review of literature and 64 cases in Japan. Acta Derm Venereol 1984, 64: 86-88

12. Kim R, Winkelmann RK: Follicular mucinosis (alopecia mucinosa). Arch Dermatol 1962, 85:490-498

13. Brown HA, Gibson LE, Pujol RM, Lust JA, Pittelkow MR: Primary follicular mucinosis: Long-term follow-up of patients younger than 40 years with and without clonal T-cell receptor gene rearrangement. J Am Acad Dermatol 2002, 47:856-862

14. Sumner WT, Grichnik JM, Shea CR, Moore JO, Miller WS, Burton CS: Follicular mucinosis as a presenting sign of acute myeloblastic leukemia. J Am Acad Dermatol 1998, 38:803-805

15. Benchikhi H, Wechsler J, Rethers L, Aubry F, Bouzouita A, Farcet JP, Revuz J, Bagot M: Cutaneous B-cell lymphoma associated with follicular mucinosis. J Am Acad Dermatol 33:673-675

16. Kim SY: Follicular mycosis fungoides. Am J Dermatopathol 1985, 7: $300-301$

17. Flaig MJ, Cerroni L, Schuhmann K, Bertsch HP, Kind P, Kaudewitz P, Sander CA: Follicular mycosis fungoides. A histopathologic analysis of nine cases. J Cutan Pathol 2001, 28:525-530

18. Rongioletti F, Smoller B: The histologic value of adnexal (eccrine gland and follicle) infiltration in mycosis fungoides. J Cutan Pathol 2000, 27:406-409

19. Gerami P, Guitart J: The spectrum of histopathologic and immunohistochemical findings in folliculotropic mycosis fungoides. Am J Surg Pathol 2007, 31:1430-1438

20. Gerami P, Rosen S, Kuzel T, Boone SL, Guitart J: Folliculotropic mycosis fungoides: An aggressive variant of cutaneous T-cell lymphoma. Arch Dermatol 2008, 144:738-746

21. Weedon D, (ed): Weedon's Skin Pathology. New York, Churchill Livingstone, 2010, 354-367

22. Coskey RJ, Mehregan AH: Alopecia mucinosa. A follow-up study. Arch Dermatol 1970, 102:193-194

23. Bonta MD, Tannous ZS, Demierre MF, Gonzalez E, Harris NL, Duncan LM: Rapidly progressing mycosis fungoides presenting as follicular mucinosis. J Am Acad Dermatol 2000, 43:635-640
24. van Doorn $R$, Scheffer E, Willemze R: Follicular mycosis fungoides, a distinct disease entity with or without associated follicular mucinosis: A clinicopathologic and follow-up study of 51 patients. Arch Dermatol 2002, 138:191-198

25. Muniesa C, Estrach T, Pujol RM, Gallardo F, Garcia-Muret P, Climent J, Servitje O: Folliculotropic mycosis fungoides: Clinicopathological features and outcome in a series of 20 cases. J Am Acad Dermatol 2010, 62:418-426

26. Lacour JP, Castanet J, Lagrange JL, Ortonne JP: Follicular mycosis fungoides: Response to radiation therapy. Br J Dermatol 1994, 130:256-257

27. Hess Schmid M, Dummer R, Kempf W, Hilty N, Burg G: Mycosis fungoides with mucinosis follicularis in childhood. Dermatology 1999, 198:284-287

28. Peters MS, Thibodeau SN, White JW Jr, Winkelmann RK: Mycosis fungoides in children and adolescents. J Am Acad Dermatol 1990, 22:1011-1018

29. Bittencourt AL, Ferras de Castro Dias N, Rocha Guimarães de Souza L, Affonso de Carvalho W: Mycosis fungoides associated with follicular mucinosis in an adolescent. Presentation of a case. Med Cutan Ibero Lat Am 1990, 18:167-169

30. Burns MK, Ellis CN, Cooper KD: Mycosis fungoides--type cutaneous T-cell lymphoma arising before 30 years of age. Immunophenotypic, immunogenotypic and clinicopathologic analysis of nine cases. J Am Acad Dermatol 1992, 27:974-978

31. Kodama K, Fink-Puches R, Massone C, Kerl H, Cerroni L: Papular mycosis fungoides: A new clinical variant of early mycosis fungoides. J Am Acad Dermatol 2005, 52:694-698

32. Cerroni L, Fink-Puches R, El-Shabrawi-Caelen L, Soyer HP, LeBoit PE, Kerl H: Solitary skin lesions with histopathologic features of early mycosis fungoides. Am J Dermatopathol 1999, 21:518-524

33. Oliver GF, Winkelmann RK: Unilesional mycosis fungoides: A distinct entity. J Am Acad Dermatol 1989, 20:63-70

34. Trüeb R, Bruckner-Tuderman L: Generalized follicular mucinosis. Hautarzt 1990, 41:625-627

35. Wittenberg GP, Gibson LE, Pittelkow MR, el-Azhary RA: Follicular mucinosis presenting as an acneiform eruption: Report of four cases. J Am Acad Dermatol 1998, 38:849-851

36. Shapiro PE, Pinto FJ: The histologic spectrum of mycosis fungoides/Sézary syndrome (cutaneous T-cell lymphoma). A review of 222 biopsies, including newly described patterns and the earliest pathologic changes. Am J Surg Pathol 1994, 18: 645-667

37. Mehregan DA, Gibson LE, Muller SA: Follicular mucinosis: Histopathologic review of 33 cases. Mayo Clin Proc 1991, 66: 387-390

38. Zelickson BD, Peters MS, Muller SA, Thibodeau SN, Lust JA, Quam LM, Pittelkow MR: T-cell receptor gene rearrangement analysis: Cutaneous $\mathrm{T}$ cell lymphoma, peripheral T cell lymphoma, and premalignant and benign cutaneous lymphoproliferative disorders. J Am Acad Dermatol 1991, 25:787-796 